\title{
Do Charter Schools Affect Property Values?*
}

\author{
John Horowitz, Stanley Keil, and Lee Spector ${ }^{+}$
}

ABSTRACT. Taxpayers are often concerned that introducing a charter school in their neighborhood will decrease their property values. We test this proposition by using three methods. We test the size and significance of the distance from a charter school with respect to property values; whether the intervention of a charter school changes the growth rate of property values; and whether the distance from a charter school has a different impact than the distance from a public school in similar neighborhoods. For the most part, we find little evidence that the existence of a charter school affects property values.

Keywords: Charter schools, property value, education, school choice

JEL Classifications: $H 75, I 21, R 53$

\section{INTRODUCTION}

This paper examines the impact of charter schools on residential property values in the surrounding neighborhoods. It falls at the nexus of three relevant literatures: that examining the school choice movement, that exploring how people form their perceptions of school quality, and that attempting to isolate the perception of neighborhood school quality from the effect of other factors affecting residential values. Most of the literature relating school quality and property values is focused on the regular public school system. While charter schools are part of the public school system, they operate in a very different manner. Thus, this paper extends the school quality/property value literature to the interesting case of charter schools.

The long dialogue and controversy generated by the school choice movement in the public policy arena provides the background for this paper. Although the focus of the paper is measuring the impact of charter schools on neighboring property values, it will be valuable to provide a short history of this dialogue and to briefly review the relevant literatures. Following this review we explain why we chose Toledo, Ohio for this study and lay out our sampling methodology and econometric models. After presenting our results we discuss our conclusions and some directions for further research.

\section{THE SCHOOL CHOICE MOVEMENT}

One of the more contentious issues in the educational policy arena is the potential implication of school choice on educational funding. In its simplest form, the public sector would take some or all of the money allocated to public school systems and send it to the schools which parents have chosen as best suited for their children. The initial wave of the school choice movement emphasized school vouchers. With vouchers, educational funds would go to the parents of school-aged children, who would then spend this money on the schools of their choice. ${ }^{1}$ Over the past several years, researchers have attempted to determine the empirical

\footnotetext{
* Our research was supported by a grant from the American Charter Schools Association. Research assistance was provided by Ms. Nattaporn Ngamsirikul and Mr. Adam Greye.

+ John Horowitz, Stanley Keil, and Lee Spector are Associate Professors of the Department of Economics, Ball State University, Muncie, IN 47304.

${ }^{1}$ See Friedman (1955) for one of the earliest discussions of vouchers. For an opposite perspective, see Witte (1996). Much of C Southern Regional Science Association 2011. 
impact on student outcome of moving to a voucher system. Investigators have compared the educational achievements between either private and public schools (Evans et al, 1995) or between experimental voucher schools and non-voucher public schools (Rouse, 1998). ${ }^{2}$ Most of these studies have examined the issue using standardized tests (Coleman et al, 1982; Goldhaber, 1996), but some have used graduation rates or graduation and college matriculation rates (Dees, 1998; Evans and Schwab, 1995). Hoxby (2002) and Arum (1996), among others, have examined the impact of private school competition on public schools. ${ }^{3}$ Still others have looked at long-term effects on such factors as wages (Card and Krueger, 1992) and long-term learning (Horowitz and Spector, 2005). Concurrently, other researchers have examined both the factors that influence parental choice of schools (West and Palsonn, 1988; Echols and Williams, 1995; Schneider and Buckley, 2002) and the relative costs of private and public schools (Peterson and Noyes, 1997; Levin and Driver, 1996).

Despite measured positive impacts, voucher schools have faced opposition from tax payers in general who for many reasons did not want give up control of the educational process to parents of school-aged children. The idea of charter schools grew out of this opposition. Charter schools would work similarly to voucher supported schools in that parents would be able to choose the charter schools appropriate for their children regardless of residential address. At the same time, charter schools would be chartered by the public sector, which would hold these schools accountable and revoke the charter if it deemed a particular school unsatisfactory.

The main arguments in favor of charter schools are very similar to the arguments in favor of vouchers as described above. First, charter schools, by allowing parental choice, would have to outperform regular public schools with respect to outcomes or costs in order to attract students. Second, like voucher schools they would lead to competition with the regular public school system, thereby improving these schools as well. The negative aspect of the voucher/charter school system is that parents might choose different qualities for their schools than the taxpayer in general might choose. This is particularly true with respect to what can be called the "non-educational" aspects of a voucher or charter school. Such non-educational factors could include religious teaching, extracurricular activities such as athletics and artistic expression, and community service. Of concern to some taxpayers would be aspects of charter schools that they perceive as impacting their property values, and to which we turn next.

\section{LITERATURE SURVEY: PUBLIC SCHOOL QUALITY \& PROPERTY VALUES}

While new schools may come into existence in response to vouchers, it is more certain that new schools will be created by the charter system. While such schools sometimes use existing space (churches, commercial property and even abandoned schools), they often represent something new in the neighborhoods where they locate and taxpayers are interested in how the addition of an experimental school, like the addition of a new store or industry, will affect property values. Yet most of the literature relating school quality and property values is focused on the regular public school system. This literature provides a foundation for the work presented in this paper.

\footnotetext{
what is said in this paper also applies to charter schools, magnet schools or choice within a given public school system.

${ }^{2}$ The comparison to private schools is done because private schools represent parental choice and it is assumed that these schools would resemble the schools that would exist if parents were the decision makers rather than the taxpayers.

${ }^{3}$ For an excellent survey of the literature on competition, see Belfield and Levin (2002).
} 
Many factors determine the value of a particular residential property. Some of these factors are attached to the building (age, size, design, and features), some are attached to the land (lot size and access to other important locations), and some are attributed to neighborhood characteristics (crime rates, air quality, quality of surrounding houses, etc.). While there is a vast literature on the determinants of residential housing values, we focus only on studies arguing that differences in school quality are capitalized in housing values. We concentrate on these articles for two reasons. First, the existence of charter schools is an outgrowth of criticism concerning school quality, and second, the articles on the relationship between property values and school quality for the most part take into account the same factors used in the more general studies.

The literature on public school quality suggests that either (1) highly rated schools may cause property values to increase or (2) high property values may result in higher quality public schools. The first argument is that quality schools attract potential residents with a consequent bidding up of residential property values near the highly ranked schools. Indeed, information about local perceptions of school quality is readily available from real estate agents and online. Most states now have websites that provide "report cards" on schools, offering information about scores on a variety of standardized tests by grade level, composite or summary statistics for each school, the demographic composition of each school, the percentage of the student body qualifying for free or subsidized meal programs, and the frequency of reported fights among students. Many new arrivals to a city actively seek this information. The second argument is that higher income homeowners are more likely to seek election to school boards and/or lobby to increase school quality via input on school hiring and expenditure decisions. If this is so, higher than average property values may cause high school quality.

There is yet another reason for being careful in interpreting a positive correlation between property values and the presence of a charter school, in that agencies creating a new charter school have more freedom in determining their location compared to public schools. Therefore, it is possible that charter schools may choose to locate in middle- or upper-income neighborhoods. For example, Henig and MacDonald (2002) find evidence that charter schools in Georgia tend to choose middle income neighborhoods with relatively large proportions of black and Hispanic residents, and higher than average home ownership rates. Thus, causation could run in either direction given a positive correlation between residence value and proximity to a school. In addition, should the Henig and MacDonald result hold generally, the positive correlation may disappear over time.

An early impetus for these educational quality studies was the desire to separate the impact of desegregation on housing values in southern cities from all other factors. For example, Jud and Watts (1981) found that failure to take into account school quality resulted in a substantial over-estimate of the impact of desegregation of a school on nearby properties. Haurin and Brasington (1996) found that school quality is an important cause of differences in the prices of residential houses. ${ }^{4}$ Each percentage point increase in the pass rate of ninth grade students on a statewide proficiency test increased house values by $\$ 400$, or about one-half of one percent of the mean house value for that data set. Likewise, Bayer, McMillan and Ferreira (2007) find that property values rise by 1 percent for each 5 percent increase in test scores.

\footnotetext{
${ }^{4}$ Haurin and Brasington (1996) had data on 45,236 single-family dwellings drawn from 140 Ohio school service boundaries. They measured quality based on the pass rate on the $10^{\text {th }}$ grade standardized tests.
} 
Still, several other writers have indicated that the measures of school quality used by Haurin and Brasington (1996) and others are not those that are used in the economics of education literature. This literature focuses on the value added or improvement in test scores between entry and exit for a particular school. In other words, it is the change in test scores, not the overall test scores, that should affect housing values. For example, Hayes and Taylor (1996) find a 0.26 percent value gain in property values for each percent increase in standardized mathematics test scores over a student's time at a particular school. On the other hand, Kane, Staiger and Samms (2003) find that it is neither current test scores nor marginal test scores that matter, but rather the reputation of the school that affects property values; thus, one should examine past test scores, not current ones. Finally, Clapp, Nanda and Ross (2008), find that demographic features are far more important than school quality. This raises the question of whether parents making a residential choice are aware of past test scores or marginal changes in test scores. Such awareness would require more investigation than determining the latest test scores. 5

Charter schools have some interesting characteristics that might lead one to believe that the impact of school quality on property values for charter schools could be quite different than that for regular public schools. Normally, proximity to a high quality school matters significantly only if a residence is inside the school's service boundary. A house immediately outside the boundary of a high quality school's service boundary may benefit from other neighborhood effects, but it is not benefiting from educational quality. Charter schools may have no service boundary or may have boundaries that coincide with many school service boundaries. To the extent that these schools provide parents with alternatives to local schools, these charter schools may reduce the premium parents are willing to pay to locate within the service boundaries of public schools historically considered high quality.

Second, the closeness to a charter school may instead become a locational choice, as it makes the commute to school similar to the commute to work. If parents are responsible for delivering children to the school, transportation savings would be capitalized in the value of properties near charter schools. However, if these transportation costs are significantly low, it is quite possible that property values would rise more in areas beyond the normal boundary of a charter school than in areas within the normal boundary. For example, Reback (2005) finds that when students can cross boundaries to go to school, housing values rise most in the areas from which students cross boundaries to go to school rather than in the area where the school is located. Further, Weimer and Wolkoff (2001), in a paper examining housing values and voucher schools, find that there is a substantial delay in students switching schools after school quality changes, which would imply that subsequent changes in housing values might also be delayed.

Third, it is also important to note that charter schools have missions that are different from those of public schools. Charter schools may serve functions that are viewed negatively (such as serving problem students, which may have a negative impact on residential housing values) or positively depending on the purpose of the charter school. Thus, how a charter school affects property values might differ substantially depending on the mission of each charter school. The success of a charter school, then, might not be related to school quality in terms of value added. For example, a very successful school that helps the disadvantaged might negatively affect property values, while a less successful school that is aimed at teaching the

\footnotetext{
${ }^{5}$ It should be pointed out that not all parents need to do this kind of research in order for quality differences in schools to be reflected in housing values.
} 
gifted might increase property values. And if quality is based on test scores rather than value added, a school that helps disadvantaged students substantially might still be thought of as being a poor quality school.

This is not to say that the real estate aspects of charter schools have been absent in the literature. In fact, there is now a growing literature on the location decisions of schools and whether charter schools are a risky real estate investment (Smith and Willcox, 2004; Kaufman Foundation, 2005). However, it must be said that both of these aspects of charter schools will have an impact on the surrounding property values. Therefore, we recognize that some of these issues overlap. It may also be the case that the long-run acceptability of charter schools may depend strongly on their impact on neighborhood residential values.

\section{GENERAL APPROACH}

Our study examines residential values before and after the opening of a charter school in a neighborhood. If charter schools have an impact on the value of a particular property, that change will not show up until the next market transaction. Even in a state that mandates market value assessment, it is not likely that assessors could estimate changes in the capitalized values of properties until some record of actual sales is available. Since we are interested in changes in property values over a relatively short period of time, we are able to ignore many of the variables that would affect the real price of constant quality houses. In particular, such variables as distance to the central business district and overall accessibility to public goods amenities (arts, parks, recreation) are fixed. Even though it is somewhat more tenuous, we assume that some of the characteristics of the house and lot also do not vary over the time period studied. Thus, except for verifying in a baseline study that the impacts of these variables in Toledo are similar to findings in other studies, we do not use such housing characteristics as number of rooms, fireplace, pool, porches, garage size, and number of floors in our analysis.

We perform our empirical analysis within the context of the Toledo metropolitan area for two reasons. First, we desired a state which had sufficient experience with charter schools to generate enough post charter school housing sales to produce usable data. Lucas County was chosen by the state of Ohio for a pilot project in 1997 to test the efficacy of charter schools in overcoming problems in what was viewed as a "challenged" school district. A significant proportion of the schools in the Toledo school district were considered to be in an "academic emergency." Two charter schools were established in 1998, an additional three in 1999. By 2004 there were 23 charter schools. Of these, eight offered "alternative education" emphasizing smaller classes, ten offered "academic excellence" approaches, one focused exclusively on high school dropouts, and one each specialized in science, performing arts, and art. One school was "on-line" only. ${ }^{6}$ Most of the schools for which we could obtain sufficient neighborhood housing data were for the most part for underachievers. Thus, we would expect them to have a negative impact, if any impact, on property values.

Second, Ohio's charter-school law is considered to be fairly flexible relative to the laws of most other states, although not as flexible as Michigan's or California's. ${ }^{7}$ Charter schools may

\footnotetext{
6 The terms "alternative education" and "academic excellence" are generally used to apply to educating students who are lagging behind their classmates in regular schools. The object may or may not be to return these students to the mainstream when they have caught up. The terms are selected by the schools for their own public relations purposes.

${ }^{7}$ A detailed description of Ohio's law is available at www.edreform.com/charter_schools/laws/CER_OhioLaw.pdf?CFID=5474988\&CFTOKEN=65374913
} 
TABLE 1. Toledo, Ohio, Total Labor Force Data for Selected Years

\begin{tabular}{lrrr}
\hline \hline & Toledo MSA & Central city Toledo & Suburbs* \\
\hline 1970 & 246,745 & 158,306 & 79,473 \\
1980 & 286,237 & 162,063 & 112,261 \\
1990 & 303,422 & 157,199 & 131,059 \\
2000 & 315,120 & 152,095 & 144,870 \\
\hline \multirow{2}{*}{ * Suburbs are Lucas, Wood, and Fulton Counties excluding the cities of Toledo and } \\
Bowling Green
\end{tabular}

be converted public schools, new start-ups, or virtual schools (there is currently a moratorium on new virtual schools). The law allows multiple chartering agencies and initial charters may be as long as five years. Automatic waivers from most state and district education laws, regulations, and policies are granted. Start-up funds are available through federal grants. In the case of district school conversions, teachers are allowed to form their own collective bargaining units or opt out of collective bargaining. Charter schools receive 100 percent of the funds equal to the community school's base formula amount, as adjusted by the cost-of-doing business factor of the school district in which the student is entitled to attend school. Per pupil support in 2005 was estimated to be about $\$ 5,629$. These funds pass directly from the state to the school. Charters may not be granted directly to for-profit organizations, but the schools may be managed by them. Transportation must be provided for students that live within 30 miles of the school. Racial mix in a charter school should be fairly close to the racial mix in its service area but not necessarily in its nearby neighborhood. Enrollment is open to all students unless the school declares that its purpose is to serve disadvantaged students only. A surplus of applicants at any particular charter school must be handled with a lottery.

Housing markets respond slowly to some changes and rapidly to others. Changes in the overall demand for houses based on changes in the local economy elicit a fairly rapid response and complicate isolating other effects on housing values. Lucas County had a population of 462,361 in 1990. By 2005, the population had fallen to 448,229. In 2003, Toledo had an estimated population of 308,973 which was down 4,800 from year 2000 and 24,000 from 1990. It is evident that Toledo has suffered from both a drop in absolute population in its metropolitan area and from suburbanization. Table 1 lists the employment data for the metropolitan area of Toledo.

These data highlight the suburbanization of employment and the general decline in employment in the central city of Toledo. The loss of employment in Lucas County is also partially a shift to Wood and Fulton Counties. Table 2 indicates the pattern of employment change for two key industrial categories. These data highlight the long-term decline in manufacturing in the central city. Much of the decline is because of the decline in the manufacturing of transportation equipment that has affected much of the Midwest.

The nearly steady decline in the Toledo city economy is strongly reflected in the median house value. The median value of owner-occupied housing units in year 2000 was $\$ 75,300$ compared to $\$ 90,700$ in Lucas County, $\$ 103,700$ for the State of Ohio and $\$ 119,600$ for the United States. Inflating 1990 housing values to year 2000's prices reveals that the real median 
TABLE 2. Employment in Manufacturing and Professional Services

\begin{tabular}{llccc}
\hline \hline & & Toledo MSA & Central city Toledo & Suburbs* \\
\hline \multirow{4}{*}{ Manufacturing } & 1970 & 73,759 & 47,876 & 25,010 \\
& 1980 & 65,639 & 36,185 & 28,267 \\
& 1990 & 57,724 & 27,660 & 28,598 \\
& $2000^{* *}$ & 59,997 & 26,605 & 31,181 \\
Professional & 1970 & 41,005 & 25,602 & 11,407 \\
Services & 1980 & 58,199 & 33,073 & 20,392 \\
& 1990 & 74,806 & 37,755 & 30,787 \\
& $2000^{* *}$ & 71,490 & 33,182 & 33,536 \\
\hline \hline
\end{tabular}

Notes * Suburbs are Lucas, Wood and Fulton Counties minus the cities of Toledo and Bowling Green.

** Industrial classifications were modified in 1998. These are estimates for the older classification.

value of occupied housing rose 13.8 percent in Lucas County but by 36 percent in the nonToledo census tracts, indicating that some neighborhoods in Toledo have recently seen declines in real house values. Thus, if school quality matters in residential value it may only be indicated by slower rates of decline in neighborhoods with quality schools. ${ }^{8}$

\section{SAMPLING FRAME}

Data for all structures with deed transfers between 1987 and the first quarter of 2006 were obtained on a CD-ROM Disk provided by the Lucas County Auditor's office. This data set included sales dates, sales amounts, deed type, assessed value of land and improvements, and some basic lot and structural characteristics for each structure. In most instances a photograph was also available. The data was accompanied by Geographic Information System software that identified the location of each structure in Lucas County and allowed the calculation of the distances from any structure to any other structure or point of interest in the county and acreages of any closed area in the county. We drew two samples. The first is a sample using all charter schools with exceptions noted below. The purpose of this sample was to examine the general impact of charter schools in a variety of settings. The second sample is used to compare property values in two non-overlapping neighborhoods, one near a charter school serving grades 7 through 12 (Toledo Accelerated Academy) and one near a public junior high/high school complex (Rogers High/McTigue Junior High). The goal was to match neighborhood characteristics as closely as possible.

Evidence from previous studies of housing values suggest that the impact of amenities (or disamenities) on housing values diminishes fairly rapidly with distance, with most of the impact of a particular amenity occurring within 2,000 feet of the amenity. ${ }^{9}$ The first sample was of houses within 2,000 feet of the selected charter schools which served K-12 populations. Because

\footnotetext{
${ }^{8}$ It must also be said that Toledo was chosen because housing market data were available at a reasonable cost for all residences with a recorded sale between 1987 and 2005, making it feasible to look at before and after data in the neighborhoods with charter schools.

${ }^{9}$ Studied amenities include parks, golf courses, churches and schools. Do e. al. (1994) estimate that the marginal impact of proximity to a church is negative up to 850 feet. Both boundary discontinuities and distance effects of schools were studied by Kane et al. (2003). The distance effect drops at 3.5 percent per mile up to the discontinuity.
} 
the neighborhoods for the second sample were less densely settled, houses within 3,000 feet of each school were used. All houses with deed transfers before and after the opening of a charter school within these distances were eligible for the sample. We attempted to reach a sampling rate of 20 percent in each neighborhood for the elementary schools and a 100 percent sampling rate for the junior high/high school sample. However, many deed transfers take place in non-market or irregular market transactions. These include intra-family transfers that are often recorded at zero price, sheriff auctions, and transfers of seized property to public housing authorities. Thus, we focused on houses that were transferred under general warranty deeds and eliminated all houses with transfer prices less than 50 percent of their assessed values. Several Charter schools were eliminated in this step of the study as they were located either in the city center or in industrial parks so that the 2000 foot distance generated no housing units. The result was a sample of 253 houses for the general sample and 170 houses in the sample used to compare Toledo Accelerated Academy with the Rogers High/McTigue Junior High complex.

Given these samples, our empirical analysis proceeds as follows:

1. We determine which variable to use as a measure of educational quality.

2. We derive a baseline model to determine if the same factors that normally affect housing values do so in Toledo. This is to ensure that Toledo data is representative of data from other possible samples.

3. We insert the distance from a charter school for each house in our sample. We then test the statistical significance of this variable in a traditional regression model.

4. We derive a forecast equation for the values of houses and determine whether the intervention of a charter school causes housing values to differ from their forecasted value.

5. We examine two like areas, one with a public school and one with a charter school, to determine whether housing values differ between these two areas.

\section{EMPIRICAL RESULTS}

\subsection{Educational Quality}

We elected to use performance indices as our school quality variable. We recognize that this decision is controversial. Thus, we decided to determine empirically whether we could extract value added information from the data available for this study. Ohio has been regularly testing elementary school students in reading, mathematical skills, science, citizenship and writing. These tests are then combined into an annual performance index $(P I)$, which is scaled from 0 to 120. These indices are readily available to the public on the Ohio Department of Education Website. Prior studies indicate that test scores are influenced by the demographic composition of the school. The problem faced by the value added approach is to separate out this influence in order to isolate the effect of the education process at the school itself.

A common formulation of the problem is to measure the influence of demographic composition as:

$$
P I_{i T}=\alpha+\gamma B \& H I S P_{i T}+\varphi S E S_{i T}+\varepsilon_{i T}
$$

(C) Southern Regional Science Association 2011. 
TABLE 3. Performance Index Relation to Race and Socioeconomic Status

\begin{tabular}{lrlrr}
\hline \multicolumn{2}{l}{$\begin{array}{l}\text { Dependent variable is } \\
\text { Included observations: }\end{array}$} & & & \\
Variable & Coefficient & Std. Error & $t$-statistic & \multicolumn{1}{c}{ Prob. } \\
\hline Constant & 77.61 & 4.204 & 18.46 & 0.00 \\
$B \& H I S P$ & -0.171 & 0.045 & -3.82 & 0.00 \\
$S E S$ & 0.174 & 0.052 & 3.35 & 0.00 \\
\hline$R^{2}$ & 0.715 & Mean dependent var & 77.79 \\
Adjusted $R^{2}$ & 0.703 & S.D. dependent var & 11.508 \\
Log likelihood & -170.89 & $F$-statistic & 62.69 \\
Durbin-Watson stat & 2.405 & Prob $(F$-statistic) & 0.000000 \\
\hline \hline
\end{tabular}

TABLE 4. Peer Group Effect on Performance Indices

\begin{tabular}{lrlrr}
\hline Dependent Variable: PI05 & & & & \\
Included observations: 53 & & & & \\
Variable & Coefficient & Std. Error & $t$-Statistic & \multicolumn{1}{c}{ Prob. } \\
\hline Constant & 23.89 & 7.639 & 3.13 & 0.00 \\
$P I 04$ & 0.747 & 0.098 & 7.59 & 0.00 \\
$B \& H I S P$ & -0.093 & 0.032 & -2.88 & 0.01 \\
SES & 0.00041 & 0.042 & 0.01 & 0.99 \\
\hline$R^{2}$ & 0.869 & Mean dependent var & 77.79 \\
Adjusted $R^{2}$ & 0.861 & S.D. dependent var & 11.50 \\
Log likelihood & -150.28 & F-statistic & 108.35 \\
Durbin-Watson stat & 1.979 & Prob $(F$-statistic $)$ & 0.000000 \\
\hline \hline
\end{tabular}

where $P I_{i T}$ is the performance index for school $i$ in year $T,{ }^{10} B \& H I S P_{i T}$ is the percent of the students that are black or Hispanic, and $S E S_{i T}$ is the percentage of students not receiving lunch support, which is a proxy for the average socio-economic status of the student body. Table 3 gives the results of a simple least-squares estimate of these effects for Toledo elementary schools. Each percent black and Hispanic and each percent of students eligible for lunch subsidy significantly lowers a school's performance index.

Since the demographic composition of a school tends to change very little from year to year, this year's performance index should only improve if the quality of the education at the school has improved. That is, this year's performance index is related to last year's performance index by the relationship:

$$
P I_{i T}=\alpha+\beta P I_{i T-1} \quad \gamma B \& H I S P_{i T}+\varphi S E S_{i T}+\varepsilon_{i T}
$$

The construct $\beta P I_{i T-1}+\gamma B \& H I S P_{i T}+\varphi S E S_{i T}$ is a proxy for the carryover of past and current peer group influence on performance. The valued added to the performance index by the school is proxied by $=\alpha+\varepsilon_{i T}$. Table 4 shows the result for estimating school and peer group effects on elementary school performance indices for the Toledo school district. In (2), SES has the

${ }^{10}$ PIO3, PI04, and PI05 used in the statistical analysis are composite performance indices for 2003, 2004, and 2005, respectively 
TABLE 5. Variables that Affect Housing Prices

\begin{tabular}{|c|c|}
\hline House Characteristics & Neighborhood Characteristics \\
\hline Age of house - $A G E$ & Distance to nearest Elementary School \\
\hline Age of roof \& utilities & Test Scores and Performance Indices for child's peer \\
\hline Number of rooms $-R O O M S$ & group at nearest elementary school $P I$ \\
\hline Number of bedrooms - BEDRMS & Distance to Central Business District DISTCC \\
\hline Number of full Baths - BATHS & Distance to recreation facilities \\
\hline Number of partial Baths & Exterior maintenance of nearby homes \& lots \\
\hline House Size & Assessed value of nearby homes \\
\hline Footprint - FPRINT & Crime rates \\
\hline Number of stories STORIES & Access to public transportation \\
\hline \multicolumn{2}{|l|}{ HAFSTORY, } \\
\hline TWOSTORY & Census Tract Data \\
\hline Garage type and size GTYPE, GSIZE & Female Heads households w/children PERFEMHEAD \\
\hline Units in same building UNITS & Percent of Households owner occupied $O W N O C P$ \\
\hline Lot Size LSIZE & Median household income $M H I N C$ \\
\hline Exterior finish $B R I C K, W O O D$ & Median commute time for employed residents $C O M T$ \\
\hline Presence of: & Percent in same house as 1995 CHURN \\
\hline Deck & Percent of residents in poverty status $P V S T A T$ \\
\hline Fire place & Percent of residents with bachelor's degree $P B A C H$ \\
\hline Air conditioning & Percent of residents that are white $P$ WHITE \\
\hline Patio & Vacancy rate $V A C A N T$ \\
\hline Pool & Unemployment rate. UNEMR \\
\hline Outbuildings & Census tract population $P O P$ \\
\hline Enclosed porch & Number of households in tract $H S H O L D S$ \\
\hline Unenclosed Porch & Percent of household with earned income PWEARN \\
\hline Fireplace & Median asking price in $2000 A S K P R$ \\
\hline 2005 Assessed Value ASSVAL & Median house age $M H A G E$ \\
\hline Most Recent Sale Date & Median rooms per housing unit $M R O O M S$ \\
\hline Most Recent Real Sale Price $L S V A L U E$ & Distance from contract centroid to city center DIST \\
\hline Sales History since 1987 & Census tract contains a school dummy $\mathrm{SCHOOL}$ \\
\hline
\end{tabular}

expected sign but is not significant. The scores from the prior year appear to imbed the influence of socio-economic status. In addition, SES and $B \& H I S P$ appear to be measuring nearly the same thing in Toledo $(\rho=-.795)$, so the coefficients are influenced by multicollinearity.

Year-to-year scores on the performance index correlate with $\rho=.92$. If there is significant variation in value added, the available school performance data from Toledo is not yet rich enough to show it. Thus, we have used the performance index alone as our measure of school quality that is readily available to parents.

\subsection{Baseline Model}

Table 5 shows the list of variables that have often been cited in the studies as affecting housing values. We have data for the italicized characteristics. In our usage, neighborhood equates to census tract level data. Because the Bureau of the Census strives to have equal 
populations in census tracts, they tend to be larger as population density decreases. Therefore, census tracts are larger the further they are from the city center. Distance from the center of the city is measured as distance from census tract centroids to the zero-zero address point at the center of the city. While all of these neighborhood characteristics can influence housing values, it is difficult to statistically separate their effects because they tend to be highly correlated. For example, one of the most noticeable characteristics of the housing market in Toledo is how rapidly housing values (land plus improvements) increase with distance from the city center (about $\$ 13,600$ per mile). Median household income and the percent of the population with bachelor's degrees also increase rapidly with distance from the center of the city. The percent of families in poverty, the percent of female headed households, unemployment rates, and ages of homes all fall significantly with distance from the center. Historically, distance from the center of the city was negatively associated with housing values. But these measures of neighborhood pathologies are intervening variables that have given rise to the "flight of the middle class" from inner cities. When these variables are combined with the dispersal of jobs from the central city that began in earnest in the 1950s, the result is that housing values (land plus improvements) now tend to increase with distance from the center of the city. Thus, the distance from the center city carries the weight of many other economic variables.

The first step in our baseline study was to determine if public elementary school quality influenced the assessed values of the 253 houses in our sample. The measure of school quality used was the Ohio Department of Education Performance Index $(P I)$, which is a weighted average of test scores in reading, writing, and mathematics (social studies and science are added for high schools). The PI was available for the years 2003 through 2005. We looked at both individual house values (253) and at the median house value for census tracts with elementary schools (49).

The general format of this model is

$$
P=\dot{\alpha}+\beta H+\gamma N+\delta P I_{03}+\varepsilon
$$

where $\alpha$ is a constant, $H$ is a vector of house characteristics with coefficients $\beta, N$ is a set of neighborhood (census tract) characteristics with coefficients $\gamma$, and $P I_{03}$ is the performance index of the highest performing school in the census tract in 2003. We are assuming that performance indices of 2003 would be most relevant to assessed values of 2005 as those are based on market activity in the previous two years. Our baseline regression results are listed in Table 6.

The adjusted $R^{2}$ of approximately .73 shows that the standard variables explain a good deal of the variation in housing values in Toledo. Furthermore, the regression shows that most of the variables that one would expect to have an impact on housing values do, in fact, have statistically significant coefficients. Only the number of vacancies and the number of stories are insignificant. However, for individual assessed values, we also find that elementary school quality as measured by the performance index has only a borderline impact on housing values in Toledo. While the coefficient suggests that assessed values rise at $\$ 426$ per one point increase in the performance index, the $t$-statistic for PIO3 is only significant at the 12-percent level. This result is weaker than that obtained by Haurin and Brasington (1996), but the sample here is at the neighborhood level while theirs is at the school district level so the results are not directly comparable. 
TABLE 6. The Baseline Model

Dependent Variable: $A S S V A L$

6.3. Included observations: 253

\begin{tabular}{lrrrr} 
Variable & Coefficient & Std. Error & $t$-statistic & Prob. \\
\hline Constant & $-31,711.35$ & $19,547.15$ & -1.62 & 0.11 \\
AGE & -29.37 & 10.72 & -2.74 & 0.01 \\
STORIES & -216.29 & $2,768.11$ & -0.08 & 0.94 \\
LSIZE & 4.977 & 0.613 & 8.12 & 0.00 \\
MHINC & 1.022 & 0.193 & 5.29 & 0.00 \\
UNITS & $-12,293.45$ & $3,386.03$ & -3.63 & 0.00 \\
BEDRMS & $10,020.86$ & $1,805.42$ & 5.55 & 0.00 \\
POP & -46.38 & 6.813 & -6.81 & 0.00 \\
PWHITE & 248.28 & 102.51 & 2.42 & 0.02 \\
UNEMR & $-2,349.45$ & $1,149.43$ & -2.04 & 0.04 \\
DISTCC & $-4,873.69$ & $2,200.10$ & -2.22 & 0.03 \\
HSHOLDS & 121.19 & 19.95 & 6.07 & 0.00 \\
VACANT & -22.87 & 46.16 & -0.50 & 0.62 \\
PIO3 & 426.18 & 272.97 & 1.56 & 0.12 \\
\hline$R^{2}$ & 0.744 & Mean dependent var & $59,836.36$ \\
Adjusted $R^{2}$ & 0.730 & S.D. dependent var & $35,542.36$ \\
S.E. of regression & $18,468.73$ & Durbin-Watson stat & 1.599 \\
$F$-statistic & 53.41 & Prob $(F$-statistic $)$ & 0.000000 \\
\hline \hline
\end{tabular}

\section{Baseline Model with the Addition of Charter Schools}

We next add proximity to charter schools to the baseline model. To do this we measured the straight line air distance of each of our 253 houses from the closest charter school. DISTCSCH represents this distance. A positive coefficient would suggest that a charter school would be a locally undesirable land use. The results are given in Table 7.

There are two striking things from this regression. First, while DISTCSCH is positive it is statistically insignificant. Second, given this result, it stands to reason that the adjusted- $R^{2}$ was not different from the baseline model. This would indicate that buyers of houses are indifferent as to whether there is a charter school in the neighborhood or not. Another way of saying this is that the other characteristics of housing dwarf the effects caused by charter schools.

\subsection{Deviations from the Expected Price of Housing}

Since it is assumed that housing characteristics do not change over the period of study, it is reasonable to expect that the influence of other factors on housing prices would remain even if a charter school had not opened in the neighborhood. We therefore assume that the general trend in housing values would have continued in the absence of the charter school, subject to changes in the performance index in the nearest elementary school. These factors set up an expected price for post charter school sale values. Thus, one way to see if charter schools have an impact on housing values is to examine the deviation of post charter school sales values from expected 
TABLE 7. Charter Schools in the Baseline Model

\begin{tabular}{lrrrr}
\hline $\begin{array}{l}\text { Dependent Variable: } A S S V A L \\
\text { Included observations: } 253\end{array}$ & & & & \\
Variable & Coefficient & Std. Error & $t$-statistic & Prob. \\
\hline Constant & $-36,535.80$ & $20,190.38$ & -1.81 & 0.07 \\
AGE & -30.77 & 10.82 & -2.84 & 0.00 \\
STORIES & -75.80 & $2,772.49$ & -0.03 & 0.98 \\
LSIZE & 4.957 & 0.6139 & 8.06 & 0.00 \\
MHINC & 0.999 & 0.1945 & 5.14 & 0.00 \\
UNITS & $-12,529.15$ & $3,395.58$ & -3.69 & 0.00 \\
BEDRMS & $9,974.50$ & $1,806.39$ & 5.52 & 0.00 \\
POP & -46.652 & 6.821 & -6.85 & 0.00 \\
PWHITE & 259.55 & 103.21 & 2.51 & 0.01 \\
UNEMR & $-2,410.65$ & $1,151.41$ & -2.09 & 0.04 \\
DISTCC & $-4,925.45$ & $2,201.15$ & -2.24 & 0.03 \\
HSHOLDS & 121.89 & 19.97 & 6.10 & 0.00 \\
VACANT & -16.772 & 46.61 & -0.36 & 0.72 \\
PIO3 & 444.37 & 273.68 & 1.62 & 0.12 \\
DISTCSCH & 2.563 & 2.679 & 0.96 & 0.34 \\
\hline$R^{2}$ & 0.7449 & Mean dependent var & $59,836.36$ \\
Adjusted $R^{2}$ & 0.7298 & S.D. dependent var & $35,542.36$ \\
S.E. of regression & $18,472.00$ & Durbin-Watson stat & 1.614 \\
F-statistic & 49.64 & Prob $(F$-statistic) & 0.000000 \\
\hline \hline
\end{tabular}

values based on a home's sales value in the latest transaction prior to the opening of the charter school and the interval between that sales value and its post charter school sales value.

The following simple model is used in our examination of the possible existence of a price effect of charter schools:

$$
P_{t}=\lambda+\theta \mathrm{E}\left(P_{t}\right)+\varphi D I S T C S C H+\psi P I_{t}+\varepsilon \mathrm{w}
$$

where $P_{t}$ is the most recent price (LSVALUE), E $\left(P_{t}\right)$ is the expected price based on the growth of nominal prices in each census tract. $\mathrm{E}\left(P_{t}\right)$ is calculated as $P_{t-1}\left(l+r_{j}\right) k$ where $P_{t-l}$ is the last sale value (PSVALUE) prior to the opening of a charter school in the neighborhood, $r_{j}$ is the geometric mean rate of change of house prices in census tract $\mathrm{j}$ during the 1990-2000 decade, and $k$ is the interval in years between the pre and post sales of each house. In Equation (4), $P I_{t}$ is the highest performance index of any elementary school within one mile of the charter school. The fundamental assumption underlying this model is that house characteristics and neighborhood characteristics remain the same in the interval studied. Table 8 shows the results for the sample for all charter schools except those located downtown and in industrial parks.

The expected price has the expected effect and is significant. Neither the performance index nor the distance to the nearest charter school is significant. The expected price likely includes the impact of local elementary school quality. Given that most of Toledo's charter 
TABLE 8. Post Charter School Sales Prices

\begin{tabular}{lrcrr}
\hline $\begin{array}{l}\text { Dependent Variable: LSVALUE } \\
\text { Included observations: 216 }\end{array}$ & & & & \\
Variable & Coefficient & Std. Error & $t$-statistic & \multicolumn{1}{c}{ Prob. } \\
\hline Constant & $18,154.17$ & $10,564.75$ & 1.72 & 0.087 \\
EXPRICE & 0.892 & 0.038 & 23.47 & 0.000 \\
DISTCSCH & 1.978 & 2.864 & 0.69 & 0.491 \\
PIO3 & -65.82 & 155.22 & -0.42 & 0.672 \\
\hline$R^{2}$ & 0.760 & Mean dependent var & $70,385.36$ \\
Adjusted $R^{2}$ & 0.756 & S.D. dependent var & $39,127.45$ \\
S.E. of regression & $19,307.82$ & Durbin-Watson stat & & 2.027 \\
$F$-statistic & 223.65 & Prob $(F$-statistic) & 0.000000 \\
\hline \hline
\end{tabular}

schools are for students lagging behind their cohort and many have published performance indices showing results substantially lower than public schools, our a priori expectation was that the coefficient of DISTCSH would be significantly negative. However, this is not the case. Thus, it might be that if the charter school in a neighborhood was primarily for gifted students the effect on property values could be positive. If and when convincing news of a value added effect becomes widespread, any type of charter school in the neighborhood might lead to a statistically significant increase in property values. At this point we can only say that introducing the charter school has not seemed to disrupt the long term trend in neighborhood housing values.

\subsection{Neighborhood Comparison of Toledo Accelerated Academy and Rogers High School.}

The purpose of this part of the study is to compare similar neighborhoods, one with a 712 grade charter school (Toledo Accelerated Academy) and the other with a junior/senior high school complex, Rogers High School/McTigue Junior High School, both of which border Rogers Park in southwest Toledo. Both neighborhoods are 90 percent non-Hispanic whites, and have house values and median incomes significantly higher than the median values for the city of Toledo. Both schools have racial compositions very different from their neighborhoods. Toledo Accelerated Academy is 12 percent non-Hispanic white, and Rogers High School is 31.9 percent non-Hispanic white. Significant transportation expenditures are required to achieve the racial mix at both schools. In our sample, the houses in the neighborhood surrounding Toledo Accelerated Academy have higher assessed values $(+\$ 22,000)$, are younger $(-14$ years), and are larger (average of +122 square feet). Even after correcting for age and size of both house and lot, there is an $\$ 18,800$ difference in house value between the neighborhoods. Median income is about $\$ 4,000$ higher in the Toledo Accelerated Academy neighborhood.

In Table 9, the variable CHARTER is a dummy with a value of 1 for all houses in the Toledo Accelerated Academy (TAA) neighborhood and zero in the Rogers High School neighborhood. It should pick up neighborhood effects. The DISTSCH variable is a measure in straight-line distance from each house to the corresponding school. It indicates that assessed values increase at $\$ 6.94$ per foot of distance from the neighborhood school. Thus, if house A is 
TABLE 9. Assessed Value with Neighborhood Effects

\begin{tabular}{|c|c|c|c|c|}
\hline \multicolumn{5}{|c|}{$\begin{array}{l}\text { Dependent Variable: } A S S V A L \\
\text { Sample: } 1170 \\
\text { Included observations: } 168\end{array}$} \\
\hline Variable & Coefficient & Std. Error & $t$-Statistic & Prob. \\
\hline Constant & $91,123.28$ & $7,371.77$ & 12.36 & 0.0000 \\
\hline$A G E$ & -279.03 & 89.72 & -3.11 & 0.0022 \\
\hline DISTSCH & 6.94 & 3.41 & 2.03 & 0.0436 \\
\hline CHARTER & $22,716.43$ & $4,068.34$ & 5.58 & 0.0000 \\
\hline$R^{2}$ & 0.2466 & Mean dep & dent var & $98,569.64$ \\
\hline Adjusted $R^{2}$ & 0.2328 & S.D. depe & lent var & $26,550.14$ \\
\hline S.E. of regression & $23,254.88$ & Durbin-W & son stat & 1.755 \\
\hline$F$-statistic & 17.89 & $\operatorname{Prob}(F$-st & & 0.000000 \\
\hline
\end{tabular}

1,000 feet more distant from either school than house B, we would expect its assessed value to be $\$ 6,940$ higher. This may reflect the general fact that high schools are perceived by assessors, if not the market, to be local nuisances due to both congestion and the large discrepancy between the racial composition of the schools and their surrounding neighborhoods.

Our basic question is whether there is a detectable difference in housing value trends in these neighborhoods that can be associated with either the presence of the charter school or the distance from either school, all other things equal. To correct for the substantial difference in the age and assessed values of the two neighborhoods, we calculated the ratios of sales values to assessed values for the period after the opening of the charter school and the ratio of actual sales values to expected sales values. Whatever effect the existing public school has on property values that effect would be the same both before and after the opening of the charter school and these ratios should not change in the public school neighborhood. Assuming that assessed values lag behind sales values by one or more years, if the charter school was to have any impact on property values recognized by buyers, these ratios should be significantly different in the charter school's neighborhood. Alternatively, for those houses for which we have before and after data, we would expect the ratio of actual to expected sales values of the houses in the charter school neighborhood to be different from those in the comparison neighborhood. Again we face the difficulty that sales values recorded by the assessor's office may not reflect open market sales.

Thus, we have further restricted the sample to houses for which the ratio of the sales value to the assessed value is greater than 0.5 and less than 2.0 (removing 20 houses) and for which the ratio of expected sales value (based on census tract trends) to actual sales value is greater than 0.2 and less than 2.0 (removing 3 additional houses).

Table 10 shows the relationship between the ratios of post charter school sales to assessed values (SALETOASVAL) in 2005. If the charter school had a positive impact on these ratios we would expect the coefficient of the CHARTER variable to be positive and significant, which is not the case. However, the entire relationship in the table is significant at the 10-percent level and the distance variable is significant at the 11-percent level, suggesting that multicollinearity is a problem. Thus, it seemed worthwhile to examine the two neighborhoods separately. 
TABLE 10. Ratio of Sales Price to Assessed Value of a Post Charter School Opening

\begin{tabular}{lrrrr}
\hline $\begin{array}{l}\text { Dependent Variable: SALETOASVAL } \\
\text { Included observations: } 148 \\
\text { Variable }\end{array}$ & Coefficient & Std. Error & $t$-statistic & \multicolumn{1}{c}{ Prob. } \\
\hline Constant & 1.154 & 0.069 & 19.38 & 0.000 \\
CHARTER & 0.024 & 0.038 & 0.636 & 0.526 \\
DISTSCH & $-4.88 \mathrm{E}-05$ & $3.04 \mathrm{E}-05$ & -1.604 & 0.111 \\
\hline$R^{2}$ & 0.032 & Mean dependent var & 1.082 \\
Adjusted $R^{2}$ & 0.019 & S.D. dependent var & 0.201 \\
S.E. of regression & 0.199 & Durbin-Watson stat & 1.688 \\
$F$-statistic & 2.40 & Prob $(F$-statistic $)$ & 0.095 \\
\hline \hline
\end{tabular}

Table 11 presents the results for the sample of houses in the charter school neighborhood. It indicates that the distance variable is negative and significant at the 5-percent level in that neighborhood. The negative coefficient indicates that the ratio of sales value to assessed value decreases as we get farther from the charter school. This is consistent with the charter school having a positive effect on housing values. But it is also consistent with the possibility that house buyers might not have as strong a negative reaction to charter schools as assessors do. No significant relationships appear in the public high school neighborhood. Our examination of actual sales values to expected sales values showed no significant relationships with any set of our variables. In particular the neighborhood dummy indicated no difference between the neighborhoods for this ratio.

Since we had sales data for the periods prior and after the opening of the charter school (i.e., we have a matched pair sample), we also examined the growth of the nominal values (VGROWTH) of the houses to see if the neighborhood made a difference. Table 12 shows that there is no significant relationship between either neighborhood or distance to a school and the growth of sales values relative to expected values. Again we examined this relationship by neighborhood but, in this case, found no significant relationships.

TABLE 11. Ratio of Sales Price to Assessed Value: Charter School Neighborhood Only

\begin{tabular}{lrcrr}
\hline \hline $\begin{array}{l}\text { Dependent Variable: SALETOASVAL } \\
\text { Included observations: } 50\end{array}$ & & & \\
Variable & Coefficient & Std. Error & $t$-statistic & Prob. \\
\hline Constant & 1.251 & 0.0597 & 20.97 & 0.00 \\
$D I S T S C H$ & -0.00012 & $4.42 E-05$ & -2.40 & 0.02 \\
\hline$R^{2}$ & .107 & Mean dependent var & 1.116 \\
Adjusted $R^{2}$ & .089 & S.D. dependent var & 0.154 \\
S.E. of regression & 0.147 & Durbin-Watson stat & 1.819 \\
$F$-statistic & 5.77 & Prob $(F$-statistic $)$ & 0.020 \\
\hline \hline
\end{tabular}


TABLE 12. Growth of Sales Price

\begin{tabular}{lrrrr}
\hline $\begin{array}{l}\text { Dependent Variable: VGROWTH } \\
\text { Included observations: } 143\end{array}$ & & & & \\
Variable & Coefficient & Std. Error & $t$-statistic & \multicolumn{1}{c}{ Prob. } \\
\hline Constant & 0.079 & 0.021 & 3.800 & 0.00 \\
INTERVAL & -0.0029 & 0.001 & -1.963 & 0.05 \\
CHARTER & -0.0032 & 0.012 & -0.263 & 0.79 \\
DISTSCH & $-4.14 \mathrm{E}-06$ & $9.53 \mathrm{E}-06$ & -0.434 & 0.66 \\
\hline$R^{2}$ & .0292 & Mean dependent var & 0.0508 \\
Adjusted $R^{2}$ & .0082 & S.D. dependent var & 0.0616 \\
S.E. of regression & 0.0613 & Durbin-Watson stat & 1.554 \\
$F$-statistic & 1.394 & Prob $(F$-statistic $)$ & 0.247 \\
\hline
\end{tabular}

\section{INTERPRETATION OF RESULTS}

We have explored several ways that charter schools could impact property values. Prior literature strongly suggests that school quality (measured by using performance indicators) positively affects housing values measured at the school district level. By focusing on census tract information, we have been able to extend the literature for elementary schools to an approximation of the service area of individual schools. We used performance indicators to make our results consistent with much of the previous literature and to correspond to our empirics concerning school quality in Toledo. We find that elementary school quality, as measured by the Ohio Department of Education Performance Index, appears to be positively associated with assessed values at the 11-percent level of significance after controlling for other house characteristics. While a higher level of significance would be desirable, our analysis suggests that Toledo property value patterns are consistent with that of other cities that have been examined.

Extending this analysis to charter elementary schools requires that we note that they differ from most public schools in that they do not have a local service area. If they did, the fact that most have uniformly lower Performance Indices than non-charter elementary schools would suggest they would depress housing values in their service area. As a surrogate for a service area, we hypothesized that charter schools have a zone of influence over residential property values that would diminish with distance of a given property to the charter school. To test this hypothesis we examined the sign and statistical significance of the coefficient on a variable measuring linear distance to a charter school in an equation in which a house's value is the dependent variable. We took several approaches to this measurement problem.

First, using a 2,000 foot radius from each charter school, we drew samples of houses that had sales transactions both before and after the opening date of the charter school. We found that the post charter school sales prices had no relationship with distance from the nearest charter school after other variables were considered. Second, we compared post charter school actual housing sale prices to both expected values based on price trends in each census tract Neither the most recent Performance Index of the nearest non-charter elementary school nor the distance from the local charter school is statistically significant.

Finally, we paired a charter high school/junior high (Toledo Accelerated Academy) with a public high school/junior high (Rogers HS/McTigue JHS)) to examine the impact of charter 
schools at the junior high-high school level. The chosen schools are in neighborhoods with similar socio-economic characteristics and racial composition. Although high school Performance Indices and graduation rates are positively associated with housing values at the district level in Ohio, we did not think that these data would be useful for this comparison. The indices for the charter school were uniformly less than 60 percent of the levels at the high school and the charter school specifically targets lagging students. For these two neighborhoods we looked at three ways in which charter schools could impact housing values. These included the impact on assessed value, on the ratio of post charter school opening sales values to assessed values and on the rate of growth of sales values treating the opening of a charter school as potentially interrupting in historical growth patterns.

The assessed value study strongly suggests that both the charter high school and the public high school act as locally undesirable land uses (LULUs). In both neighborhoods assessed values increase with distance from the school. There could be several reasons why this pattern is observed. Traffic congestion, occasional unruly behavior, and the disparity between the racial composition of the schools and the surrounding neighborhoods may all account for lowered housing values near the schools. Finally, changes in assessed values tend to lag changes in market values by some years. If charter schools impact nearby housing values, this should show up in larger deviations of post charter school sales prices from assessed values and a significant interrupt in growth of values in the charter school neighborhood relative to the public school neighborhood. Neither of these hypotheses is corroborated by the statistical results.

\section{CONCLUSIONS}

We draw the following conclusions from the data from Toledo:

1. Elementary charter schools do not appear to affect property values either positively or negatively in nearby neighborhoods.

2. The charter high school appears to have roughly the same effect on property values as the public high school. That is, it acts as a locally undesirable land use which reduces value for some distance, and

3. In terms of sales to assessed value ratios or growth rates of values, there is no difference between the charter school neighborhood and the public school neighborhoods.

These conclusions are, of course, conditional upon the usefulness of the choices made in generating the samples used. The primary choice was that of using Toledo, a city whose charter school movement grew out of a strong perception of a district school system in crisis, and which had seen strong suburbanization of higher income families and a long term decline in economic activity. These factors suggest several lines for future research. In this end, the approach used in this paper might also be useful in providing a road map for doing this research.

\section{REFERENCES}

Arum, Richard. (1996) "Do Private Schools Force Public Schools to Compete?," American Sociological Review, 61, 29-46.

Bayer, Patrick J., Robert McMillan, and Fernando V. Ferreira. (2007) "A Unified Framework for Measuring Preferences for Schools and Neighborhoods," NBER Working Paper No. W13236. 
Belfield, Clive R. and Henry M. Levin. (2002) "The Effects of Competition between Schools on Educational Outcomes: A Review for the United States," Review of Educational Research, 72, 279-341.

Card, David and Alan Krueger. (1992) "Does School Quality Matter? Returns to Education and the Characteristics of Public Schools in the United States," Journal of Political Economy, 100, 1-39.

Clapp, John M., Anupam Nanda, and Stephen L. Ross. (2008) "Which School_Attributes Matter? The Influence of School Service Boundary Performance and Demographic Composition on Property Values," Journal of Urban Economics, 63, 451-466.

Coleman, James S., Thomas Hoffer, and Sally Kilgore. (1982) High School Achievement: Public, Catholic, and Private Schools. Basic Books: New York.

Dees, Thomas (1998) "Competition and the Quality of Public Schools," Economics of Education Review, 17, 419-427.

Do, A. Quang, Robert W. Wilbur, and James L. Short (1994) "An Empirical Examination of the Externalities of Neighborhood Churches on Housing Values," Journal of Real Estate Finance and Economics, 9, 127-136

Echols, Frank H. and John Douglas Willms. (1995) "Reasons for School Choice in Scotland," Journal of Educational Policy, 10, 143-156.

Evans, William N. and Robert M. Schwab. (1995) "Finishing High School and Starting College: Do Catholic Schools Make a Difference?," Quarterly Journal of Economics, 110, 941974.

Friedman, Milton. (1955) "The Role of Government in Education," in Robert A. Solo (ed.), Economics and the Public Interest: Essays Written in Honor of Eugene Ewald Agger. Rutgers University Press; New Brunswick, NJ, pp. 123-144.

Goldhaber, Dan D. (1996) "Public and Private High Schools: Is School Choice an Answer to the Productivity Problem?," Economics of Education Review, 15, 93-109.

Haurin, Donald R. and David Brasington. (1996) "School Quality and Real House Price: Intraand Interjurisdictional Effects," Journal of Housing Economics, 5, 351-368.

Hayes, Kathy J. and Lori L. Taylor. (1996) "Neighborhood School Characteristics: What Signals Quality to Homebuyers?," Economic Review, Federal Reserve Bank of Dallas, iss. 4, 2-9.

Henig, Jeffrey R. and MacDonald, Jason A. (2002) "Locational Decisions of Charter Schools: Probing the Market Metaphor,” Social Science Quarterly, 84, 962-980.

Horowitz, John B. and Lee C. Spector. (2005) "Is There a Difference between Private and Public Education on College Performance?," Economics of Education Review, 24, 189-195.

Hoxby, Caroline M. (2002) "Does Competition among Public Schools Benefit Students and Taxpayers?," American Economic Review, 90, 1209-1238.

Jud, G. Donald and James M. Watts. (1981) “Schools and Housing Values," Land Economics 57: 459-470. 
Kane, Thomas J., Douglas G. Staiger, and Gavin Samms. (2003) "School Accountability Ratings and Housing Values," In William G. Gale and Janet R. Pack (eds.), Brookings-Wharton Papers on Urban Affairs, pp. 83-137.

Levin, Henry M. and Cyrus E. Driver. (1996) "Estimating Costs of an Educational Voucher System,” In William J. Fowler, Jr., (ed.), Selected Papers in School Finance 1994. U. S. Department of Education, National Center for Education Statistics: Washington, D.C., pp. 63-87. Available in December 2010 at http://nces.ed.gov/pubs/96068.pdf.

Peterson, Paul E. and Chad Noyes. (1997) “Under Extreme Duress, School Choice Success,” In Diane Ravitch and Joseph Viteritti (eds.), New Schools for a New Century: The Redesign of Urban Education. Yale University Press: New Haven, CT, pp. 123-146.

Reback, Randall. (2005) "Property Values and the Provision of Local Public Services: Capitalization under School Choice Programs," Journal of Urban Economics, 57, 275301.

Rouse, Cecilia E. (1998) "Private School Vouchers and Student Achievement: An Evaluation of the Milwaukee Parental Choice Program," Quarterly Journal of Economics, 113, 553602.

Schneider, Mark and Jack Buckley. (2002) What Do Parents Want from Schools? Evidence from the Internet. Educational Evaluation and Policy Analysis, 24, 133-144.

Smith, Kim and James Willcox. (2004) "A Building Need: Charter Schools in Search of Good Homes," Education Next, 4(2), 44-51. Available in December 2010 at http://newschools.org/files/ABuildingNeed.pdf,

Weimer, David L. and Michael J. Wolkoff. (2001) "School Performance and Housing Values: Using Non-Contiguous District and Incorporation Boundaries to Identify School Effects," National Tax Journal, 54, 231-253.

West, Edwin and Halldor Palsson. (1988) "Parental Choice of School Characteristics: Estimation Using State-wide Data," Economic Inquiry, 26, 725-740.

Witte, John F. (1996) "School Choice and Student Performance," Chapter 5 in Helen Ladd (ed.), Holding Schools Accountable. The Brookings Institution: Washington, D.C., pp. 149176. 